\title{
Stable isotopic composition of top consumers in Arctic cryoconite holes: revealing divergent roles in a supraglacial trophic network
}

\author{
Tereza Novotná Jaroměřská ${ }^{1}$, Jakub Trubač ${ }^{2}$, Krzysztof Zawierucha ${ }^{3}$, Lenka Vondrovicová2 ${ }^{2}$ Miloslav Devetter ${ }^{4,5}$, \\ and Jakub D. Žárský ${ }^{1}$ \\ ${ }^{1}$ Department of Ecology, Faculty of Science, Charles University, Prague, 128 44, Czech Republic \\ ${ }^{2}$ Institute of Geochemistry, Mineralogy and Mineral Resources, Faculty of Science, Charles University, \\ Prague, 128 43, Czech Republic \\ ${ }^{3}$ Department of Animal Taxonomy and Ecology, Adam Mickiewicz University, Poznań, 61-614, Poland \\ ${ }^{4}$ Institute of Soil Biology, Biology Centre, Czech Academy of Sciences, České Budějovice, 370 05, Czech Republic \\ ${ }^{5}$ Centre for Polar Ecology, University of South Bohemia, České Budějovice, 370 05, Czech Republic
}

Correspondence: Tereza Novotná Jaroměřská (jaromert@ natur.cuni.cz)

Received: 10 February 2020 - Discussion started: 24 February 2020

Revised: 15 January 2021 - Accepted: 18 January 2021 - Published: 4 March 2021

\begin{abstract}
Arctic cryoconite holes represent highly biologically active aquatic habitats on the glacier surface characterized by the dynamic nature of their formation and functioning. The most common cryoconite apex consumers are the cosmopolitan invertebrates - tardigrades and rotifers. Several studies have highlighted the potential relevance of tardigrades and rotifers to cryoconite holes' ecosystem functioning. However, due to the dominant occurrence of prokaryotes, these consumers are usually out of the major scope of most studies aimed at understanding biological processes on glaciers. The aim of this descriptive study is to present pioneering data on isotopic composition of tardigrades, rotifers and cryoconite from three High Arctic glaciers in Svalbard and discuss their role in a cryoconite hole trophic network. We found that tardigrades have lower $\delta^{15} \mathrm{~N}$ values than rotifers, which indicates different food requirements or different isotopic fractionation of both consumers. The $\delta^{13} \mathrm{C}$ values revealed differences between consumers and organic matter in cryoconite among glaciers. However, the mechanistic explanation of these variations requires further investigation focused on the particular diet of cryoconite consumers and their isotopic ratio. Our study introduces the first observation of carbon and nitrogen stable isotopic composition of top consumers in cryoconite holes analysed by an improved method for cryoconite sample processing, paving the way for further studies of the supraglacial trophic network.
\end{abstract}

\section{Introduction}

Supraglacial habitat, the environment on the glacier surface, is subjected to a continuous as well as episodic input of allochthonous and autochthonous material and forms a biogeochemical reactor involving a variety of biotic and abiotic processes. Most of the biotic activity is usually connected to ablation zones (areas with an ice loss exceeding its gain) which have a global tendency to increase their surface area due to climate change (Hodson et al., 2008; Stibal et al., 2012a). Moreover, the export of the biological communities and their metabolic production has the potential to influence the downstream deglaciated areas and coastal marine ecosystems (Bardgett et al., 2007; Foreman et al., 2007; Hodson et al., 2008; Hood et al., 2009; Williams and Ferrigno, 2012).

The accumulated fine material on the glacier surface (socalled cryoconite; Nordenskiöld, 1875) - due to its dark colour - reduces albedo of the glacier ice and creates waterfilled depressions called cryoconite holes (Cook et al., 2016; Takeuchi et al., 2001). The diameter and the depth of cryoconite holes usually range from a few centimetres to tens of centimetres (Gerdel and Drouet, 1960; Fountain et al., 2004; Zawierucha et al., 2018a, 2019a). At the bottom of the holes, cryoconite forms aggregates (cryoconite granules) composed of bacteria and organic and inorganic matter (Takeuchi et al., 2001) which provide a suitable environment for various organisms (Zawierucha et al., 2015, 2021). The sup- 
ply of organic and inorganic matter into cryoconite holes is restricted to allochthonous input from atmospheric deposition, weathering of mineral dust, aeolian deposition and local bird guano deposition (Anesio et al., 2009; Benassai et al., 2005; Edwards et al., 2014; Hodson et al., 2005; Stibal et al., 2008; Telling et al., 2011; Vonnahme et al., 2016; Xu et al., 2010; Žárský et al., 2013). The autochthonous input of matter is generally restricted to microbial activity and recycling (Telling et al., 2011, 2012). Moreover, adjacent areas of glaciers can vary a lot in terms of topography, geology, vegetation and stage of soil development. Therefore, the allochthonous matter brought to the glacial surface can influence the composition of its surface material and biota (Grzesiak et al., 2015; Marshall and Chalmers, 1997; Stibal et al., 2008).

Cryoconite holes cover about $7 \%$ of the surface of the ablation zone (Bøggild et al., 2010; Fountain et al., 2004; Stibal et al., 2012b) and form the most nutrient-rich and biologically active habitats within the supraglacial environment (Cameron et al., 2012; Hodson et al., 2008). As mentioned by Säwström et al. (2002), the rate of photosynthesis in cryoconite holes is comparable with rates of polar lakes, and consequently the rate of respiration and utilization of organic matter is very high (Hodson et al., 2008). Thus, cryoconite holes form an important net carbon sink or source in polar ecosystems which depends on the balance between autotrophic and heterotrophic production (Stibal et al., 2012a). Moreover, due to their high biological activity, cryoconite holes efficiently retain nutrients (Bagshaw et al., 2013), and the accumulated matter can consequently provide a source of important nutrients moving into adjacent areas (Anesio et al., 2010; Porazinska et al., 2004). Therefore, the impact of cryoconite holes on glacier ecosystems' nutrient pathways (e.g. carbon, nitrogen and other microelements) and on downstream ecosystems is a key component for an understanding of the glacial ecosystems' functioning (Anesio et al., 2010; Bagshaw et al., 2013; Stibal et al., 2012a; Telling et al., 2011).

Organisms inhabiting cryoconite holes range from bacteria, algae and fungi to metazoans such as tardigrades (phylum Tardigrada) and rotifers (phylum Rotifera) (Cook et al., 2016; Kaczmarek et al., 2016; Zawierucha et al., 2015, 2021). Tardigrades and rotifers are cosmopolitan microscopic invertebrates contributing to multiple aquatic and terrestrial trophic levels as carnivorous, herbivorous, omnivorous and microbivorous species (Guidetti et al., 2012; Guil and Sanchez-Moreno, 2013; Hallas and Yeates, 1972; Kutikova, 2003). Due to their ability to survive various extreme conditions (Guidetti et al., 2011; Ricci, 2001), these animals represent a large component of microfauna in polar and high mountain regions and are the exclusive metazoans inhabiting cryoconite holes in the Arctic (Zawierucha et al., 2018a, 2019b).

As the top consumers of Arctic cryoconite holes, tardigrades and rotifers may represent an important driver of the community of primary producers by grazing and nutrient recycling, thus setting stoichiometric constraints on the local community (Elser and Urabe, 1999; Vonnahme et al., 2016; Zawierucha et al., 2018a, 2021). Previous research on biota from cryoconite holes on Svalbard archipelago has revealed that the size distribution and concentration of algae, particularly Zygnematales and Chlorococcales, correlates with the community structure of consumers represented by tardigrades and rotifers (Vonnahme et al., 2016). Documented correlations indicate that grazing likely has an impact on the structure of primary producers in cryoconite holes and presumably contributes to available nutrient quantities and ratios in cryoconite. Nevertheless, other studies from the margin of the Greenland ice sheet have revealed a lack of quantitative relations between the numbers of top consumers and potential food such as cyanobacteria and algae (Zawierucha et al., 2018a) and demonstrated the variability in supraglacial systems which is influenced by multiple factors occurring on various glaciers (Porazinska et al., 2004). As described by Střítecká and Devetter (2015), tardigrades and rotifers are efficient filtrators and especially rotifers reveal high filtration rates in cryoconite holes. The feeding behaviour and morphology of the feeding apparatus indicate that cryoconite species consume mostly algae, bacteria and detritus (Devetter, 2009; Iakovenko et al., 2015; Zawierucha et al., 2016). However, their diet in various environments differs interspecifically (Guidetti et al., 2012; Guil and Sanchez-Moreno, 2013; Hallas and Yeates, 1972; Kutikova, 2003; Mialet et al., 2013; Wallace and Snell, 2010; Zawierucha et al., 2016).

Analyses of stable isotopes are a well-developed tool which enables us to uncover the trophic interactions of organisms within various systems (McCutchan et al., 2003; O'Reilly et al., 2003; Wada, 2009; Yoshii et al., 1999). Because of the differences in isotopic fractionation, $\delta^{13} \mathrm{C}$ and $\delta^{15} \mathrm{~N}$ isotopic values of organisms and their potential food can reflect their possible mutual relationships and positions within the food web (Michener and Lajtha, 2008). Isotopic fractionation is caused by physical or biochemical processes which favour lighter or discriminate heavier isotopes (Michener and Lajtha, 2008). The $\delta^{13} \mathrm{C}$ value reflects the diet of the organism and is similar or slightly higher within the animal compared to its food (Peterson and Fry, 1987). The slight increase between organismal $\delta^{13} \mathrm{C}$ and the $\delta^{13} \mathrm{C}$ values of its diet is caused by a higher assimilation of heavier ${ }^{13} \mathrm{C}$ supported by the discrimination against ${ }^{13} \mathrm{C}$ during respiration (Blair et al., 1985; DeNiro and Epstein, 1978; Ekblad and Högberg, 2000; Wada, 2009). Therefore, the process of consumption and growth generally tends to increase the $\delta^{13} \mathrm{C}$ within the consumer's body compared to its diet. However, larger variations in $\delta^{13} \mathrm{C}$ are balanced by a higher release of ${ }^{13} \mathrm{C}$ during excretion (DeNiro and Epstein, 1978). The $\delta^{15} \mathrm{~N}$ values reflect the nitrogen isotopic composition of the organism's diet and point to the position of organisms in a food chain (DeNiro and Epstein, 1981). The $\delta^{15} \mathrm{~N}$ value is usually higher in the animal body compared to its diet 
and increases with the trophic level (DeNiro and Epstein, 1981; Kling et al., 1992; Zah et al., 2001). This increase is mostly caused by a higher proportion of proteins within the diet and subsequent preferential excretion of ${ }^{14} \mathrm{~N}$ during protein metabolism (Kling et al., 1992; McCutchan et al., 2003). Furthermore, if the environment is limited by a specific nutrient, the consumer's body fractionates isotopes differently than in the case of no nutrient limitation (Michener and Lajtha, 2008; Šantrůček et al., 2018). For example, Adams and Sterner (2000) described that if the diet had a high C: N ratio, the $\delta^{15} \mathrm{~N}$ of the consumer's body increased. Another study demonstrated that if the diet is limited by a nutrient, the consumer's body tends to increase or decrease the fractionation against heavier isotope to keep its isotopic values almost constant (Aberle and Malzahn, 2007). Stable isotopes of carbon and nitrogen are the most common food web tracers used in ecological studies (Michener and Lajtha, 2008). In the case of invertebrates, many studies focus on aquatic or soil food webs where producers and consumers can be easily collected and prepared, and their body size enables us to create the required number of analyses with a sufficient number of individuals (e.g. Ponsard and Arditi, 2000; Wada, 2009). Several studies have also focused on carbon and nitrogen stable isotopes in polar areas (Almela et al., 2019; Shaw et al., 2018; Velázquez et al., 2017). However, none of them have been on glaciers, which are an intrinsic part of polar ecosystems and high mountain areas.

The primary producers such as cyanobacteria and algae are an important biotic component reflecting differences in the nutrient input on the glacier surface and contributing to the glacial ecosystem functioning (Hodson et al., 2008; Stibal et al., 2012b; Vonnahme et al., 2016). Studies focusing on the role of top consumers in cryoconite holes are lacking, however, which may hinder our understanding of cryoconite holes' and glacial ecosystems' ecology. This study is based on data from three High Arctic inland glaciers, all three located in a different geomorphological and geological context. We expected that different geomorphological characteristics would be reflected in the input of organic matter and thus in the composition of its consumers (Cameron et al., 2012; Edwards et al., 2013a, b). The current state of knowledge about abundances and feeding rates of glacier invertebrates suggests that they possess a substantial capacity to influence the biotic fluxes of nutrients and energy on the glacier surface. Therefore, we assume that the activity of invertebrates is likely an important component of the nutrient recycling in the glacier system with possible implications for downstream ecological processes. Here we apply the stable isotope analysis to examine whether the top consumers - tardigrades and rotifers - show probable differences in their food sources in the glacial ecosystem and discuss their trophic position in cryoconite holes. This work presents the first evidence of differences in food sources or isotopic fractionation in two widespread groups of glacier invertebrates and is an important step in the ongoing research focusing on underlying mechanisms in the observed patterns.

\section{Material and methods}

\subsection{Study site and sampling}

Samples of cryoconite were collected from three glaciers (Ebbabreen, Nordenskiöldbreen and Svenbreen; breen means glacier in Norwegian) located in central Svalbard $\left(78^{\circ} \mathrm{N}, 14-17^{\circ} \mathrm{E}\right)$ during July and August 2016. Svenbreen is a representative of small glaciers in the geologically older part of the Billefjorden Fault Zone. Ebbabreen and Nordenskiöldbreen are larger valley glaciers within a geologically younger zone. On each glacier, representative cryoconite holes (varied in shape, size and depth) were sampled in the upper (close to the equilibrium line) and the lower (closer to the glacier terminus) part of the ablation zone around the main axis of the glacier. Sampling was conducted twice from each glacier (within the interval of approximately 1 week between each sampling) using a high-density polyethylene (HDPE) bottle with two siphons according to Mueller et al. (2001) with modifications after Vonnahme et al. (2016). Cryoconite samples from each part of the ablation zone were poured together and put into sterile Whirl-Pak ${ }^{\circledR}$ bags (Nasco, Fort Atkinson, WI). Water $\mathrm{pH}$ was measured during the sampling by a Hanna Instruments tester (HI 98130). Data about the air temperature were provided by the meteorological station at Bertilbreen which is a glacier adjacent to the examined Svenbreen. After sampling, cryoconite was stored on ice in a field refrigerator (a plastic barrel entrenched into permafrost) and subsequently frozen at $-20^{\circ} \mathrm{C}$ and kept frozen until analysis.

\subsection{Preparation of samples for isotopic analyses}

For each replicate, a part of cryoconite $\left(\sim 2-4 \mathrm{~cm}^{3}\right)$ was separately melted by dropping distilled water through the sample into a glass beaker, transferred into a falcon tube and stored in a cooling box. Animals were collected under a light microscope (Olympus CX31 and Leica DM750) using a glass Pasteur pipette. All work was performed using nitrile gloves to avoid carbon contamination. Every individual specimen was cleaned of superficial mineral and organic particles and transferred at least once to a drop of clean distilled water before transferring into an Eppendorf tube. The Eppendorf tubes were also continuously cooled by a cooling pad. The collected individuals were stored in a freezer at $-20^{\circ} \mathrm{C}$ until lyophilization and further processing started. After at least 300 individuals of both taxa (tardigrades and rotifers) were collected from each sample, the Eppendorf tubes were thawed and all individuals from each sample were transferred into a pre-weighted tin capsule (Costech 41077, $5 \times 9 \mathrm{~mm}$ ). If the water content in the capsule exceeded onehalf of the volume, capsules were dried inside a desiccator 
with silica gel $(0.5-2.5 \mathrm{~h})$ until the water inside the capsules was reduced to one-third of the volume. The samples were consequently frozen at $-20^{\circ} \mathrm{C}$, and at least half an hour before the lyophilization they were stored at $-80^{\circ} \mathrm{C}$. The duration of the lyophilization was $4 \mathrm{~h}$. Thereafter, samples were weighed (Mettler Toledo Excellence Plus XP6; linearity $=0.0004 \mathrm{mg}$ ), and the capsules were closed and wrapped and analysed immediately or stored in a desiccator until the analyses were performed. The average dry weight of invertebrates in the capsule was $\sim 29.5 \mu \mathrm{g}$. Also, since the identification of species requires specific preparation (see Sect. 2.5), samples for isotopic analyses were pooled samples of all species occurring in used cryoconite. Four replicates of tardigrades, rotifers and cryoconite from Svenbreen; five replicates of tardigrades, four replicates of rotifers and three replicates of cryoconite from Nordenskiöldbreen; and three replicates of tardigrades, two replicates of rotifers and two replicates of cryoconite from Ebbabreen were collected for the isotopic analyses. Due to the adaptation of cryoconite consumers to specific conditions occurring on the glacier surface (e.g. low temperature, low content of available nutrients), we modified commonly used methods to avoid alteration of their chemical composition during the preparation for isotopic analyses.

Cryoconite intended for the isotopic analyses was cleaned from tardigrades and rotifers, which were collected in parallel for isotopic analyses described above. After the collection, cryoconite was stored in Eppendorf tubes at $-20^{\circ} \mathrm{C}$. When all samples were prepared, cryoconite was homogenized using an agate pestle and mortar and dried in a thin layer on a Petri dish at $45^{\circ} \mathrm{C}$. The duration of drying was $8 \mathrm{~h}$.

For the analyses of $\delta^{15} \mathrm{~N}$ in organic matter $(\mathrm{OM})$, cryoconite was transferred without any other preparation into pre-weighed tin capsules (Costech 41077, $5 \times 9 \mathrm{~mm}$ ) and weighed. The average amount of cryoconite used for analyses was $\sim 31 \mathrm{mg}$. For the analyses of $\delta^{13} \mathrm{C}$ in organic matter, 11-12 mg of cryoconite was transferred into pre-weighed silver capsules (Elemental Microanalysis, $8 \times 5 \mathrm{~mm}$, D2008) and carbonates (e.g. calcite, dolomite) were dissolved using $10 \% \mathrm{HCl}$ moistened with $\mathrm{diH}_{2} \mathrm{O}$. The acid was pipetted into the capsules followed by additions of 10, 20, 30, 50 and $100 \mu \mathrm{L}$ with drying after each addition according to Brodie et al. (2011) with the modification after Vindušková et al. (2019). After the last acid addition, samples were left drying at $50^{\circ} \mathrm{C}$ for $17 \mathrm{~h}$. After drying, silver capsules were inserted into tin capsules and put into a desiccator for 10 $20 \mathrm{~d}$.

\subsection{Stable isotopes analyses}

The $\delta^{13} \mathrm{C}$ and $\delta^{15} \mathrm{~N}$ values in all samples were analysed using a Flash 2000 elemental analyser (Thermo Fisher Scientific, Bremen, Germany). Released gases $\left(\mathrm{NO}_{x}, \mathrm{CO}_{2}\right)$ separated in a gas chromatography column were transferred to a Delta $\mathrm{V}$ Advantage isotope-ratio mass spectrometer (Thermo Fisher
Scientific, Bremen, Germany) through a capillary by a Continuous Flow IV system (Thermo Fisher Scientific, Bremen, Germany). The stable isotope results are expressed in standard delta notation $(\delta)$ with samples measured relative to the Pee Dee Belemnite for carbon isotopes and atmospheric $\mathrm{N}_{2}$ for nitrogen isotopes and normalized to a regression curve based on international standards IAEA-CH-6, IAEA-CH-3 and IAEA-600 (International Atomic Energy Agency, Vienna) for carbon and IAEA-N-2, IAEA-N-1 and IAEA-NO-3 (International Atomic Energy Agency, Vienna) for nitrogen. The regression curve of the total gas for analyses of cryoconite was based on the international standards Soil Standard Peaty OAS (Elemental Microanalysis, UK) and Soil Standard Clay OAS (Elemental Microanalysis, UK). Analytical precision as a long reproducibility for standards was within $\pm 0.03 \%$ o for $\delta^{13} \mathrm{C}$ and $\pm 0.02 \%$ o for $\delta^{15} \mathrm{~N}$.

The isotopic values of nitrogen in $\mathrm{OM}$ as well as organic carbon (decarbonized cryoconite) in cryoconite were used as a reference to the isotopic composition of potential food sources for the invertebrates.

\subsection{X-ray diffraction}

To reveal the differences in geological composition of sediment among the three glaciers, mineral phases of homogenized sediment were determined by an X-ray diffraction analysis on the Panalytical X'Pert Pro (PW3040/60) with an X'Celerator detector. The measurements were conducted under the following conditions: radiation $-\mathrm{CuK} \alpha, 40 \mathrm{kV}$, $30 \mathrm{~mA}$; angular range -3 to $70^{\circ} 2 \theta$; step $0.02^{\circ} / 150 \mathrm{~s}$. The results were evaluated using an X'Pert HighScore Plus 1.0d software program with a JCPDS PDF-2 (ICDD, 2002) database.

\subsection{Cryoconite holes' community composition}

For the species identification, at least $10 \mathrm{~cm}^{3}$ of cryoconite was used from each sample. Tardigrades were collected using a glass Pasteur pipette, and the first observation was made under a stereomicroscope (Olympus SZ51). Immediately after collecting, clean tardigrades were transferred onto glass slides and mounted in a small drop of Hoyer's medium (Anderson, 1954; Ramazzotti and Maucci, 1983). After $1 \mathrm{~d}$ of drying in $56^{\circ} \mathrm{C}$, tardigrades were identified under a light microscope with phase contrast (Olympus BX53) associated with a digital camera ARTCAM-500. Due to the ambiguities associated with the identification of cryoconite species (species complexes and hidden molecular lines; Zawierucha et al., 2020), tardigrades were classified into the trophic groups based on the dominant feeding behaviour and feeding apparatus morphology according to Guidetti et al. (2012), Guil and Sanchez-Moreno (2013), Hallas and Yeates (1972), and Kosztyła et al. (2016). Specimens of bdelloid rotifers were identified using a compound light microscope when moving (identification is performed using the morphology of 
their cirri and trophi). Identification of feeding behaviour of rotifers was primarily conducted following the monograph by Doner (1965). For the identification of eukaryotic primary producers, small drops of thawed and well-mixed cryoconite were placed on the mount. Afterwards, algae and cyanobacteria were identified using a light microscope Olympus BX51 equipped with Nomarski interference contrast and the digital camera Canon EOS 700D. Identification was based on publications by Ettl and Gärtner (2014), Starmach (1966), and Wehr et al. (2015). Quantification of primary producers was omitted due to the preservation of samples by freezing which presumably has a taxon-specific effect on the survival of cells of the phototrophs. This presumption is based on the observed low survival rate of glacial algal cells (Mesotaenium, Ancylonema) in freeze-thaw cycles (Jakub D. Žárský, personal communication, 2020). The proportional representation of consumers in each sample was calculated during the collecting of tardigrades and rotifers for isotopic analyses, and it is presented as frequency (in \%) relative to the total number of collected animals on each glacier. A difference in relative abundance lower than $5 \%$ was considered an equal proportion.

\subsection{Statistical analyses}

All statistical analyses were conducted in $\mathrm{R}$ version 3.5.3 ( $\mathrm{R}$ Development Core Team, 2018). To test the differences between $\delta^{15} \mathrm{~N}$ isotopic values of tardigrades and rotifers, a Kruskal-Wallis rank sum test was used. Before the correlation coefficient tests were applied, a Shapiro-Wilk test was used to test the normal distribution of the data. Therefore, the Pearson's rank correlation coefficient was calculated for all the correlations between isotopic values $\left(\delta^{13} \mathrm{C}\right.$ and $\left.\delta^{15} \mathrm{~N}\right)$ of cryoconite and isotopic values of tardigrades and rotifers which were normally distributed. The $\delta^{15} \mathrm{~N}$ of tardigrades and frequency of omnivorous tardigrades among glaciers were non-normally distributed; thus Spearman's productmoment correlation coefficient was used. Correlation coefficients using the Shannon-Wiener index of diversity were used to reveal differences between species composition and isotopic values $\left(\delta^{15} \mathrm{~N}, \delta^{13} \mathrm{C}\right)$ of tardigrades. To compare isotopic values of tardigrades, rotifers and cryoconite from each sampling site, one-way ANOVA and Tukey multiple comparisons of means were applied. For the purpose of statistical analyses, all replicates from the same sampling campaigns were averaged.

\section{Results}

\subsection{Mineral composition and characteristics of cryoconite}

X-ray diffraction of cryoconite showed that the glaciers differ in mineral composition. Svenbreen has a low amount of dolomite and amphibole which are dominantly found within the metamorphic basement rocks around Ebbabreen and Nordenskiöldbreen. The distribution of minerals within each glacier is shown in Table A1 (Appendix). ANOVA applied to the mean $\delta^{13} \mathrm{C}$ values of $\mathrm{OC}$ in cryoconite did not reveal any significant difference between glaciers. Due to logistical issues, $\mathrm{pH}$ in cryoconite holes was measured only on Svenbreen and Nordenskiöldbreen with $\mathrm{pH}<7$.

\subsection{Isotopic values}

The isotopic value of nitrogen showed significant differences in $\delta^{15} \mathrm{~N}$ between tardigrades and rotifers in all samples (Kruskal-Wallis $\chi^{2}=12.685$; $\mathrm{df}=1, n=22$; $p$ value $=0.00037)$. All measured $\delta^{15} \mathrm{~N}$ values of tardigrades revealed lower $\delta^{15} \mathrm{~N}$ values than rotifers as shown in Fig. 1 and Table 1.

Furthermore, we measured $\delta^{15} \mathrm{~N}$ values of nitrogen in organic matter from cryoconite, but there was no significant relation with $\delta^{15} \mathrm{~N}$ values of tardigrades and rotifers found.

Regarding the isotopic values of carbon, we found a positive correlation of the $\delta^{13} \mathrm{C}$ values of decarbonized cryoconite and the $\delta^{13} \mathrm{C}$ of rotifers (Pearson's product-moment correlation $r=0.83 ; n=19 ; p$ value $=0.006)$ (Fig. 2a). The respective relationship among tardigrades was not significant (Pearson's product-moment correlation $r=0.67 ; n=$ $21 ; p$ value $=0.07)($ Fig. $2 b)$.

In all samples, differences in $\delta^{13} \mathrm{C}$ and $\delta^{15} \mathrm{~N}$ of tardigrades and rotifers and differences in $\delta^{13} \mathrm{C}$ of decarbonized cryoconite among glaciers were tested using ANOVA with the mean values of $\delta^{13} \mathrm{C}$ and $\delta^{15} \mathrm{~N}$ and the Tukey multiple comparisons of means. These analyses showed a significant difference in $\delta^{13} \mathrm{C}$ values of rotifers between glaciers $(p$ value $=0.029)($ Fig. 3a $)$, mostly between Nordenskiöldbreen and Svenbreen $(p$ value $=0.025)$. All other tests did not reveal any significant pattern (Fig. 3).

\subsection{Cryoconite holes' community composition}

During the collection of animals for isotopic analyses, we counted the frequency of tardigrades and rotifers within all replicates (Table 1). On all three glaciers, tardigrades and rotifers co-occurred. However, Svenbreen revealed dominance of rotifers from the total number of 7375 collected individuals, Ebbabreen was dominated by tardigrades from the total number of 5163 collected individuals, and Nordenskiöldbreen revealed an equal proportion of tardigrades and rotifers from the total number of 6401 collected individuals. 
Table 1. Description of samples and isotopic values $\left(\delta^{13} \mathrm{C}, \delta^{15} \mathrm{~N}\right)$ of tardigrades, rotifers and cryoconite. Isotopic values are presented in per mille and related to the international standards of the Pee Dee Belemnite for carbon and atmospheric $\mathrm{N}_{2}$ for nitrogen. The $\delta^{13} \mathrm{C}^{*}$ are values of cryoconite after carbonate removal. The frequency of consumers on each glacier is expressed in percent relative to the total quantity of collected consumers for isotopic analyses. $T$ signifies tardigrades, and $R$ signifies rotifers.

\begin{tabular}{lrr|rr|rr|rr}
\hline Glacier & \multicolumn{2}{c|}{ Tardigrades } & \multicolumn{2}{c|}{ Rotifers } & \multicolumn{2}{c|}{ Cryoconite } & Frequency \\
\cline { 2 - 9 } & $\delta^{15} \mathrm{~N}$ & $\delta{ }^{13} \mathrm{C}$ & $\delta^{15} \mathrm{~N}$ & $\delta^{13} \mathrm{C}$ & $\delta{ }^{15} \mathrm{~N}$ & $\delta^{13} \mathrm{C}^{*}$ & $T$ & $R$ \\
\hline Sven & -3.55 & -23.75 & -1.57 & -27.09 & -2.20 & -22.65 & 39 & 61 \\
& -4.04 & -26.36 & -1.81 & -26.69 & -2.17 & -22.08 & & \\
& -3.52 & -26.33 & -2.04 & -31.16 & -2.24 & -24.09 & & \\
\hline \multirow{2}{*}{ Nordenskiöld } & -4.39 & -26.45 & -1.04 & -28.53 & -1.64 & -23.25 & & \\
& -3.49 & -22.91 & -2.20 & -23.36 & -3.58 & -21.56 & 49 & 51 \\
& -3.76 & -22.30 & -1.72 & -23.25 & -2.30 & -20.56 & & \\
& -4.15 & -24.78 & -3.30 & -23.02 & -2.98 & -22.52 & & \\
\hline Ebba & -3.93 & -25.11 & & & & & & \\
& -1.73 & -24.19 & 0.69 & -26.32 & -2.30 & -22.24 & 58 & 42 \\
& -4.85 & -25.22 & -2.38 & -25.13 & -4.29 & -23.31 & & \\
\hline
\end{tabular}

Regarding the species composition of primary producers, we identified representatives of algae and cyanobacteria from all samples. In the case of algae, we observed mostly Zygnematales (Ancylonema sp., Mesotaenium sp.). In the case of cyanobacteria, we observed Oscillatoriales (Phormidium sp.), Nostocales (Nostoc) and Synechococcales (Leptolyngbya sp.).

During the division of consumers into trophic groups, only tardigrades were identified in a sufficient number for analyses. Rotifers found within the samples were identified as Macrotrachella sp. and Adineta sp. However, they could not be divided and analysed due to the majority of individuals occurring in a dormant stage, which made it impossible to observe the morphology of their cirri and trophi (jaws) necessary for their identification. Regarding tardigrades, we identified 1117 individuals which were divided into three trophic groups: Pilatobius glacialis Zawierucha et al., 2020 as microbivores (41\%), hypsibiids (Acutuncus mariae Zawierucha et al., 2020 and representatives of Hypsibius dujardini group) as herbivores (53\%) and Grevenius cryophilus Zawierucha et al., 2020 as omnivores (5\%). We also found a few individuals of Cryoconicus kaczmareki Zawierucha et al., 2018b on Ebbabreen, but they were not included in statistics due to their very rare occurrence. As shown in Fig. 4, the composition of tardigrade trophic groups is slightly different among glaciers.

Correlations between trophic groups of tardigrades and isotopic values $\left(\delta^{15} \mathrm{~N}, \delta^{13} \mathrm{C}\right)$ of tardigrades and decarbonized cryoconite did not reveal any significant relationship.

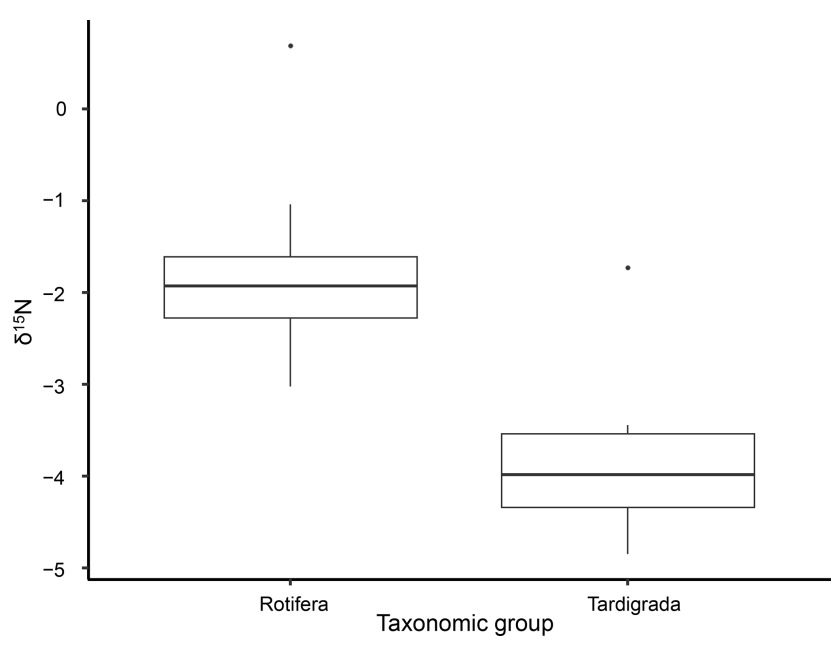

Figure 1. Differences in $\delta^{15} \mathrm{~N}$ between tardigrades and rotifers analysed by Kruskal-Wallis rank sum test. The diagram displays medians and distribution of measured $\delta^{15} \mathrm{~N}$ values. The whiskers represent the lowest and highest measured values. Both outliers represent $\delta^{15} \mathrm{~N}$ values of one replicate from Ebbabreen.

\section{Discussion}

\subsection{Isotopic values and the role of consumers in cryoconite trophic network}

The nitrogen isotopic values of cryoconite consumers revealed higher $\delta^{15} \mathrm{~N}$ in rotifers compared to tardigrades, suggesting differences in the $\delta^{15} \mathrm{~N}$ of their diet or differences in the isotopic fractionation between both consumers. Predominantly, higher values of $\delta^{15} \mathrm{~N}$ usually indicate a higher 

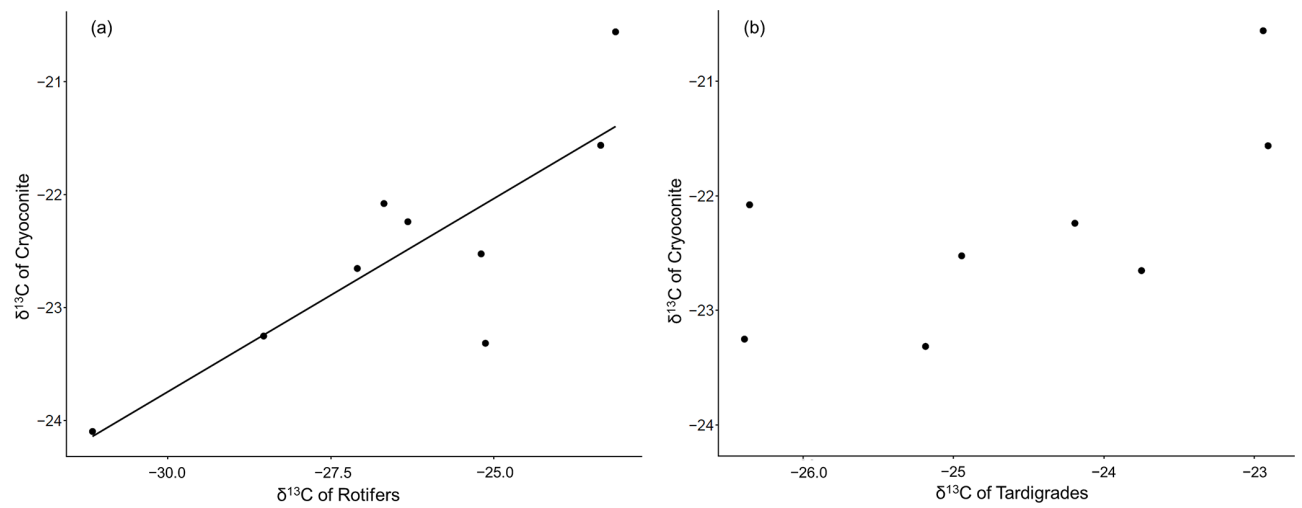

Figure 2. Correlation between decarbonized cryoconite and (a) $\delta^{13} \mathrm{C}$ of rotifers with the linear regression line and (b) tardigrades.
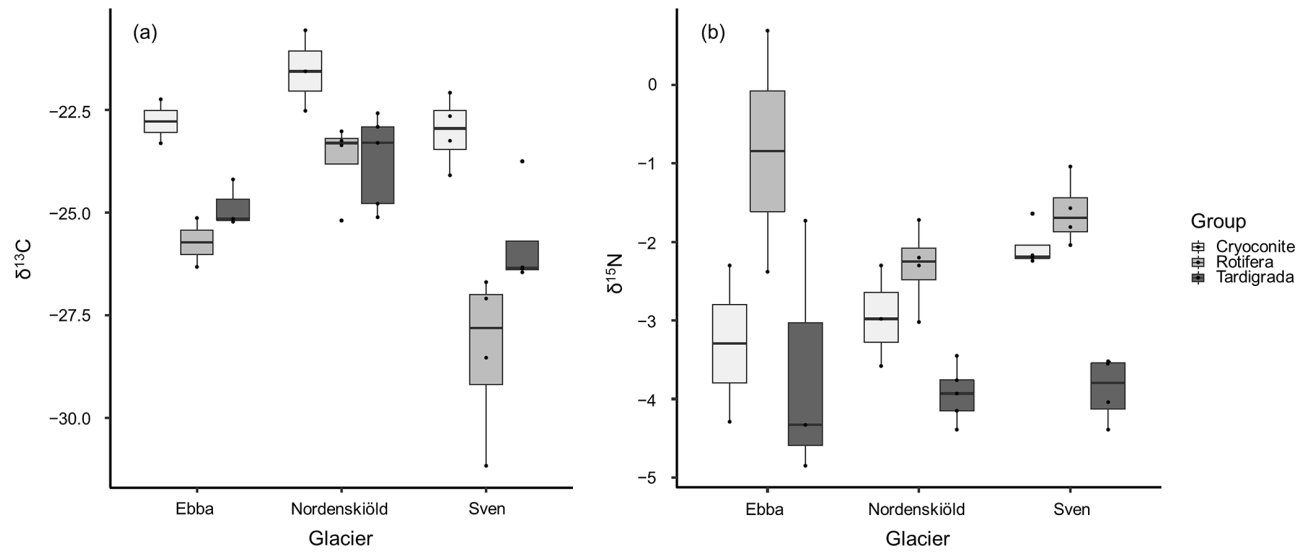

Figure 3. Distribution of $\delta^{13} \mathrm{C}(\mathbf{a})$ and $\delta^{15} \mathrm{~N}(\mathbf{b})$ isotopic values in tardigrades $(n=12)$, rotifers $(n=10)$ and cryoconite $(n=9)$ among glaciers. The differences in variances among glaciers are the result of the low number of replicates.

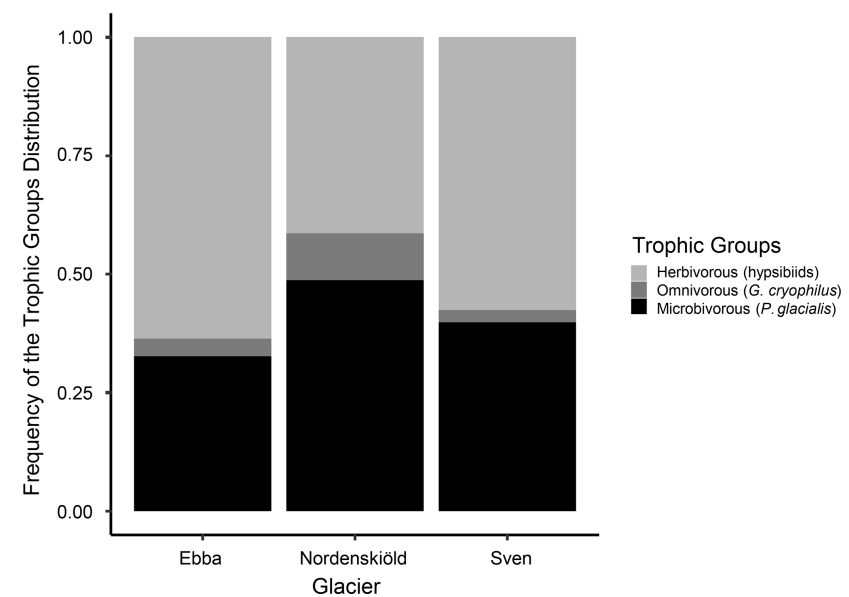

Figure 4. Bar plot visualization of tardigrades' trophic-group relative distribution among glaciers. trophic level (Kling et al., 1992; Wada, 2009). However, based on the observed food preferences of tardigrades and rotifers from cryoconite (Stř́itecká and Devetter, 2015; Zawierucha et al., 2016), we cannot presume their strict trophic division, nor can we clearly distinguish their feeding strategies. Rotifers were mostly identified as filter feeders (Macrotrachella sp.) or scrapers (Adineta sp.) (Herzig et al., 2006) whereas Adineta sp. did not exceed Macrotrachella sp. in the total quantity of collected rotifers (the living specimens can be well distinguished from Macrotrachella sp. during collecting). Tardigrades found in samples were identified as microbivorous (P. glacialis), herbivorous (hypsibiids) and omnivorous (G. cryophilus) species. Nevertheless, based on the knowledge of the tardigrades' feeding apparatus morphology, P. glacialis with its ventrally located mouth is likely able to consume algae during scratching biofilms from the surface of granules and G. cryophilus, which has a relatively wide buccal tube, can utilize various food sources such as algae, protozoans and other small invertebrates. Moreover, all studied groups of tardigrades feed on algae in laboratory cultures (Bryndová et al., 2020; Kosztyła et al., 2016). 
Therefore, we assume that the differences in $\delta^{15} \mathrm{~N}$ between both consumers may suggest enrichment of ${ }^{15} \mathrm{~N}$ in food for rotifers caused by preferential consumption of bacteria or dissolved organic matter (DOM) and consequently higher $\delta^{15} \mathrm{~N}$ compared to food for tardigrades (Altabet and Small, 1990; Kling et al., 1992; Mariotti et al., 1980; McCutchan et al., 2003; Peterson and Fry, 1987). The results of Nagarkar et al. (2004) and Kohler et al. (2018), who reported that cyanobacteria have high content of proteins and high $\delta^{15} \mathrm{~N}$ values typical of nitrogen-fixing organisms, serve as an indirect empirical indication supporting this assumption. However, lower $\delta^{15} \mathrm{~N}$ of tardigrades may suggest the variation in $\delta^{15} \mathrm{~N}$ of algae which can vary depending on their $\mathrm{C}: \mathrm{N}$ ratio and $\delta^{15} \mathrm{~N}$ ratio of their nitrogen source (Adams and Sterner, 2000; Gu and Alexander, 1993). The differences between consumers may also signify different nitrogen isotopic fractionation depending on the $\mathrm{C}: \mathrm{N}$ ratio of their food (Aberle and Malzahn, 2007; Adams and Sterner, 2000). Moreover, we cannot exclude the possibility that consumers in cryoconite holes may be limited by the lack of nutrients; thus the ingested food composition may shift from its optimum compared to related species from other habitats.

Regarding the $\delta^{13} \mathrm{C}$ values, tardigrades and rotifers in our study revealed lower $\delta^{13} \mathrm{C}$ than decarbonized cryoconite. This difference is similar to the results described by Almela et al. (2019) and Velázquez et al. (2017), who focused on tardigrades and rotifers from Antarctic microbial mats, but it contrasts with the fundamental literature (Peterson and Fry, 1987; Wada, 2009) as well as with the study of Shaw et al. (2018), who focused on soil in the non-glaciated part of the Taylor Valley (Antarctica). We assume that these variations may be explained by differences in carbon fractionation on glacier surfaces, differences within tardigrades and rotifers in comparison with freshwater zooplankton and soil microfauna, or the variations in isotopic values of various species which differed in their frequencies among glaciers. The correlation between $\delta^{13} \mathrm{C}$ of cryoconite and rotifers may also indicate that rotifer food represents much of the cryoconite organic carbon. Such correlation in tardigrades was not significant, which could be because they potentially consume algae and cyanobacteria that incorporate $\mathrm{CO}_{2}$ from the atmosphere during photosynthesis with similar $\delta^{13} \mathrm{C}$ values everywhere. The results presenting the distribution of $\delta^{13} \mathrm{C}$ in comparison with differences in $\delta^{15} \mathrm{~N}$ between tardigrades and rotifers may indicate that rotifers consume DOC originating from extracellular exudates of algae or cyanobacteria (Velázquez et al., 2017), but the source of nitrogen (e.g. bacteria, cyanobacteria and organic detritus) is likely different.

In comparison with studies focusing on the isotopic composition of consumers from soil and microbial mats in Antarctica (Almela et al., 2019; Shaw et al., 2018; Velázquez et al., 2017), isotopic composition of tardigrades and rotifers from Arctic cryoconite holes reveals differences in $\delta^{15} \mathrm{~N}$ as well as in $\delta^{13} \mathrm{C}$. Nevertheless, even though studies from Antarctica present different isotopic values, they include im- portant data about relations of tardigrades and rotifers to the main food sources within studied systems, revealing information about the diet of these polar invertebrates and supporting our assumption that both groups probably do not strictly divide their food sources, and therefore a further examination of their gut content is necessary. For example, in Almela et al. (2019), tardigrades were related mostly to a larger fraction of particulate organic matter $(\mathrm{POM}<30 \mu \mathrm{m})$ composed generally of green algae and rotifers were related to a smaller fraction of POM $(0.5-5 \mu \mathrm{m})$ composed generally of bacteria and detritus. In the study of Velázquez et al. (2017), tardigrades were related to cyanobacteria and POM $(<30 \mu \mathrm{m})$ and rotifers mostly to cyanobacteria and diatoms. Regarding the isotopic composition, the closest values to our results were observed in tardigrades and rotifers from soil in Taylor Valley (Shaw et al., 2018) in which these consumers were considered mat grazers.

It is known that the absolute isotopic composition varies among systems based on various causes, such as differences in the isotopic composition of the nutrient pool (Montoya et al., 1990), seasonal changes in the community structure (Cifuentes et al., 1988), seasonal variability in isotopic values of the food (Zah et al., 2001) or the effect of temperature on the isotopic fractionation (Bosley et al., 2002; Degens et al., 1968; Hinga et al., 1994; Olive et al., 2003). Thus, our results from cryoconite holes, in which the input of nutrients as well as changes in the community structure of microbes varies during the season (Säwström et al., 2002; Stibal et al., 2008), require further investigation focused on isotopic composition of the gut content in tardigrades and rotifers and their isotopic fractionation and elemental ratio to fully reveal the causes of their different isotopic values.

\subsection{Variations in isotopic values among glaciers}

As shown in the results, the isotopic values among glaciers revealed differences in $\delta^{13} \mathrm{C}$ of rotifers primarily between Nordenskiöldbreen and Svenbreen. The frequency of consumers on these two glaciers showed a higher abundance of rotifers at Svenbreen and an equal abundance of tardigrades and rotifers at Nordenskiöldbreen. Nordenskiöldbreen also revealed a higher quantity of presumably microbivorous $P$. glacialis compared to Svenbreen where presumably herbivorous hypsibiids dominated.

The differences in $\delta^{13} \mathrm{C}$ values may indicate specific nutrient requirements of primary producers affected by the variability in spatial characteristics of the glacier surroundings and consequent variations in the nutrient input onto the glacier surface (Bagshaw et al., 2013; Hagen et al., 1993). As presented by Post (2002), who focused on freshwater food webs, larger studied lakes evinced higher $\delta^{13} \mathrm{C}$ values than small lakes, suggesting higher occurrence of autochthonous carbon input increasing the $\delta^{13} \mathrm{C}$ of the food web. Based on these findings, we assume that due to its smaller size, Svenbreen may have a higher allochthonous input of nutri- 
ents in the form of organic matter from adjacent habitats, which could lower the $\delta^{13} \mathrm{C}$ because of a longer chain of fractionations discriminating against heavier ${ }^{13} \mathrm{C}$ as is typical of an allochthonous source of carbon (Peterson and Fry, 1987; Post, 2002). Consequently, the depletion in the ${ }^{13} \mathrm{C}$ of consumers on Svenbreen could signify preferential consumption of DOM from the primary production or detritus (Abelson and Hoering, 1961; Iakovenko et al., 2015; Macko and Estep, 1984). Oppositely, consumers from Nordenskiöldbreen and Ebbabreen revealed higher $\delta^{13} \mathrm{C}$ which could be a result of the larger size of these glaciers and a potential larger component of autochthonous production (Stibal et al., 2010) which uses enriched carbon from atmospheric $\mathrm{CO}_{2}$ (Post, 2002) and has a shorter chain of transformations and discriminations against ${ }^{13} \mathrm{C}$ during the assimilation of inorganic matter (Michener and Lajtha, 2008). Nevertheless, the observed variations in $\delta^{13} \mathrm{C}$ among glaciers could also reflect a different proportional representation of herbivorous and other consumers (DeNiro and Epstein, 1978; Michener and Lajtha, 2008) or a dynamical character of sudden processes occurring on the glacial surface including changes in the input of organic and inorganic matter (Chandler et al., 2015; Telling et al., 2012; Wagenbach et al., 1996; Zah et al., 2001). Therefore, further investigations focused on carbon isotopic ratios and fractionation in cryoconite holes are essential.

Regarding the differences in $\delta^{15} \mathrm{~N}$ among glaciers, some samples evinced a high presence of cyanobacteria Leptolyngbya sp. which may relate to $\delta^{15} \mathrm{~N}$ variations between glaciers due to a higher content of ${ }^{15} \mathrm{~N}$ in the populations of cyanobacteria (Darby and Neher, 2012). However, as described in Sect. 2.5, we were not able to quantify primary producers; thus, our observation may be influenced by inaccuracies caused by the preservation of samples by freezing.

During the analyses of mineral composition of cryoconite, we detected a high amount of amphibole and dolomite on Ebbabreen and Nordenskiöldbreen which are both located in a geologically younger zone of the Billefjorden Fault Zone compared to Svenbreen located in an older part of the Billefjorden Fault Zone. Considering a higher potential solubility of minerals due to acidic $\mathrm{pH}$ of cryoconite holes (4.485.9) and differences in mineral composition of cryoconite aggregates among glaciers, the differences in the community structure of microbial communities and consequent isotopic values may be related to the variability in composition of available minerals released by biogeochemical weathering (Barker and Banfield, 1998; Carson et al., 2007; Roberts et al., 2004; Zawierucha et al., 2019c). Moreover, upper parts of Svenbreen were covered by snow during sampling, whereas before and during sampling of Ebbabreen, the air temperature increased to $8.8^{\circ} \mathrm{C}$ (according to the meteorological station at Bertilbreen). Therefore, the higher content of $\delta^{15} \mathrm{~N}$ in these samples could also be caused by the presence of $\mathrm{NO}_{3}^{-}$ in the meltwater (Hodson et al., 2005).

\section{Conclusions}

This study presents the first description of carbon and nitrogen isotopic values of cryoconite consumers (tardigrades and rotifers) and their potential food. Despite the variability in distribution of isotopic values, we showed that $\delta^{15} \mathrm{~N}$ differs between tardigrades and rotifers in all samples which points to their different roles in a cryoconite trophic network. The $\delta^{13} \mathrm{C}$ values revealed variability in their distribution among the taxa as well as between glaciers suggesting that the input and source of carbon among glaciers may differ and influence the isotopic composition of $\delta^{13} \mathrm{C}$ in cryoconite as well as in consumers. We also revealed a significant correlation between organic carbon from decarbonized cryoconite and rotifers, which may indirectly indicate that rotifers are more related to cryoconite carbon from bacteria than are tardigrades, which are likely considered to be more herbivorous. Nevertheless, further research is required to elucidate and explain the cryoconite trophic network, the entire diet of the consumers and their contribution to supraglacial nutrient pathways. 


\section{Appendix A}

Table A1. Mineral composition in particular samples analysed by X-ray diffraction. The $\times$ symbol means presence of the mineral; $\times \times$ means high presence of the mineral. The sign "_" means that the mineral was not detected. Abbreviations of samples refer to the glacier where the cryoconite was sampled, the part of the ablation zone and the number of the sampling session.

\begin{tabular}{lccccccc}
\hline Sample & Quartz & Plagioclase & K-feldspar & Amphibole & Dolomite & $\begin{array}{c}\text { Muscovite or } \\
\text { illite }\end{array}$ & Chlorite \\
\hline SL1 & $\times \times$ & $\times$ & $\times$ & - & - & $\times \times$ & $\times$ \\
SU1 & $\times \times$ & $\times$ & $\times$ & - & - & $\times$ & $\times$ \\
SL2 & $\times \times$ & $\times$ & $\times$ & - & - & $\times \times$ & $\times \times$ \\
SU2 & $\times \times$ & $\times$ & $\times$ & $\times$ & $\times$ & $\times \times$ & $\times \times$ \\
NL1 & $\times \times$ & $\times$ & $\times$ & $\times$ & $\times$ & $\times \times$ & $\times \times$ \\
NU1 & $\times \times$ & $\times$ & $\times$ & $\times$ & $\times$ & $\times \times$ & $\times \times$ \\
NL2 & $\times \times$ & $\times$ & $\times$ & $\times$ & $\times$ & $\times \times$ & $\times \times$ \\
EL2 & $\times$ & $\times$ & $\times$ & $\times$ & $\times \times$ & $\times \times$ & $\times \times$ \\
EU2 & $\times \times$ & $\times$ & $\times$ & $\times$ & $\times$ & $\times \times$ & $\times \times$ \\
\hline
\end{tabular}


Code availability. All codes related to figures and analyses were made in $\mathrm{R}$ (version 3.5.1) and are available upon request to the corresponding author.

Data availability. All data about isotopic composition, trophicgroup composition and mineral composition are available upon request to the corresponding author. Meteorological data from Bertilbreen were kindly provided by Kamil Láska, and all requests must be sent to him.

Author contributions. JDŽ, TNJ, JT and KZ developed the study design. The field sampling was conducted by TNJ and JDŽ. The stable isotopes analyses were conducted by TNJ, JT and LV. The identification of trophic groups of tardigrades was conducted by TNJ and KZ. The identification of rotifers was conducted by MD. TNJ compiled and processed all presented data and prepared the manuscript with revisions from all co-authors.

Competing interests. The authors declare that they have no conflict of interest.

Acknowledgements. We thank the Stable and Radiogenic Isotope Research Laboratory at the Faculty of Science, Charles University, and the Laboratory of X-ray Diffraction of the Institute of Geochemistry, Mineralogy and Mineral Resources, Faculty of Science, Charles University (operator Petr Drahota), for all support with cryoconite analyses. Furthermore, we would like to thank Jack Middelburg, Paul Bartels and both the anonymous referees for their careful revisions and thorough comments and Pavel Škaloud, Jakub Štenc, Pavel Pipek, Petra Seifertová, Helena Hubáčková, Jan Soumar, Dan Vondrák, David Novotný and Marina Bukovcak for their specialized help with the determination of primary producers, statistics, lyophilization and manuscript preparation. We also want to thank Kamil Láska who kindly provided meteorological data from Bertilbreen. Special thanks go to the Cryosphere Ecology Group and the Department of Ecology at Charles University.

Financial support. This research was supported by a Charles University research grant (GA UK, grant no. 596120 awarded to Tereza Novotná Jaroměřská), the Centre for Polar Ecology and Czech Arctic Polar Infrastructure of University of South Bohemia - Josef Svoboda Station in Svalbard (project CzechPolar LM2015078 supported by the Ministry of Education, Youth and Sports), the foundation Nadání Josefa, Marie a Zdenky Hlávkových, the Mobility Fund of Charles University, the internationalization funding of Charles University, and the Center for Geosphere Dynamics (grant no. UNCE/SCI/006). Studies on organic matter, the role of invertebrates and productivity of glacial ecosystems were supported via grant NCN 2018/31/B/NZ8/00198 awarded to Krzysztof Zawierucha.
Review statement. This paper was edited by Jack Middelburg and reviewed by two anonymous referees.

\section{References}

Abelson, P. H. and Hoering, T. C.: Carbon isotope fractionation in formation of amino acids by photosynthetic organisms, P. Natl. Acad. Sci. USA, 47, 623, https://doi.org/10.1073/pnas.47.5.623, 1961.

Aberle, N. and Malzahn, A. M.: Interspecific and nutrientdependent variations in stable isotope fractionation: experimental studies simulating pelagic multitrophic systems, Oecologia, 154, 291-303, https://doi.org/10.1007/s00442-007-0829-5, 2007.

Adams, T. S. and Sterner, R. W.: The effect of dietary nitrogen content on trophic level ${ }^{15} \mathrm{~N}$ enrichment, Limnol. Oceanogr., 45 , 601-607, https://doi.org/10.4319/lo.2000.45.3.0601, 2000.

Almela, P., Velázquez, D., Rico, E., Justel, A., and Quesada, A.: Carbon pathways through the food web of a microbial mat from Byers Peninsula, Antarctica, Front. Microbiol., 10, 628, https://doi.org/10.3389/fmicb.2019.00628, 2019.

Altabet, M. A. and Small, L. F.: Nitrogen isotopic ratios in fecal pellets produced by marine Zooplankton, Geochim. Cosmochim. Ac., 54, 155-163, https://doi.org/10.1016/0016-7037(90)90203W, 1990.

Anderson, L. E.: Hoyer's solution as a rapid permanent mounting medium for bryophytes, Bryologist, 57, 242-244, 1954.

Anesio, A. M., Hodson, A. J., Fritz, A., Psenner, R., and Sattler, B.: High microbial activity on glaciers: importance to the global carbon cycle, Glob. Change Biol., 15, 955-960, https://doi.org/10.1111/j.1365-2486.2008.01758.x, 2009.

Anesio, A. M., Sattler, B., Foreman, C., Telling, J., Hodson, A., Tranter, M., and Psenner, R.: Carbon fluxes through bacterial communities on glacier surfaces, Ann. Glaciol., 51, 32-40, https://doi.org/10.3189/172756411795932092, 2010.

Bagshaw, E. A., Tranter, M., Fountain, A. G., Welch, K., Basagic, H. J., and Lyons, W. B.: Do cryoconite holes have the potential to be significant sources of $\mathrm{C}, \mathrm{N}$, and $\mathrm{P}$ to downstream depauperate ecosystems of Taylor Valley, Antarctica?, Arct. Antarct. Alp. Res., 45, 440-454, https://doi.org/10.1657/1938-4246-45.4.440, 2013.

Bardgett, R. D., Richter, A., Bol, R., Garnett, M. H., Bäumler, R., Xu, X., Lopez-Capel, E., Manning, D. A., Hobbs, P. J., Hartley, I. R., and Wanek, W.: Heterotrophic microbial communities use ancient carbon following glacial retreat, Biol. Letters, 3, 487490, https://doi.org/10.1098/rsbl.2007.0242, 2007.

Barker, W. W. and Banfield, J. F.: Zones of chemical and physical interaction at interfaces between microbial communities and minerals: a model, Geomicrobiol. J., 15, 223-244, https://doi.org/10.1080/01490459809378078, 1998.

Benassai, S., Becagli, S., Gragnani, R., Magand, O., Proposito, M., Fattori, I., Traversi, R., and Udisti, R.: Seaspray deposition in Antarctic coastal and plateau areas from ITASE traverses, Ann. Glaciol., 41, 32-40, https://doi.org/10.3189/172756405781813285, 2005.

Blair, N., Leu, A., Muñoz, E., Olsen, J., Kwong, E., and Des Marais, D.: Carbon isotopic fractionation in heterotrophic microbial metabolism, Appl. Environ. Microb., 50, 996-1001, 1985. 
Bøggild, C. E., Brandt, R. E., Brown, K. J., and Warren, S. G.: The ablation zone in northeast Greenland: ice types, albedos and impurities, J. Glaciol., 56, 101-113, https://doi.org/10.3189/002214310791190776, 2010.

Bosley, K. L., Witting, D. A., Chambers, R. C., and Wainright, S. C.: Estimating turnover rates of carbon and nitrogen in recently metamorphosed winter flounder Pseudopleuronectes americanus with stable isotopes, Mar. Ecol.-Prog. Ser., 236, 233-240, https://doi.org/10.3354/meps236233, 2002.

Brodie, C. R., Leng, M. J., Casford, J. S., Kendrick, C. P., Lloyd, J. M., Yongqiang, Z., and Bird, M. I.: Evidence for bias in $\mathrm{C}$ and $\mathrm{N}$ concentrations and $\delta^{13} \mathrm{C}$ composition of terrestrial and aquatic organic materials due to preanalysis acid preparation methods, Chem. Geol., 282, 67-83, https://doi.org/10.1016/j.chemgeo.2011.01.007, 2011.

Bryndová, M., Stec, D., Schill, R. O., Michalczyk, Ł., and Devetter, M.: Dietary preferences and diet effects on lifehistory traits of tardigrades, Zool. J. Linn. Soc., 188, 865-877, https://doi.org/10.1093/zoolinnean/zlz146, 2020.

Cameron, K. A., Hodson, A. J., and Osborn, A. M.: Structure and diversity of bacterial, eukaryotic and archaeal communities in glacial cryoconite holes from the Arctic and the Antarctic, FEMS Microbiol. Ecol., 82, 254-267, https://doi.org/10.1111/j.15746941.2011.01277.x, 2012.

Carson, J. K., Rooney, D., Gleeson, D. B., and Clipson, N.: Altering the mineral composition of soil causes a shift in microbial community structure, FEMS Microbiol. Ecol., 61, 414-423, https://doi.org/10.1111/j.1574-6941.2007.00361.x, 2007.

Chandler, D. M., Alcock, J. D., Wadham, J. L., Mackie, S. L., and Telling, J.: Seasonal changes of ice surface characteristics and productivity in the ablation zone of the Greenland Ice Sheet, The Cryosphere, 9, 487-504, https://doi.org/10.5194/tc-9-487-2015, 2015.

Cifuentes, L. A., Sharp, J. H., and Fogel, M. L.: Stable carbon and nitrogen isotope biogeochemistry in the Delaware estuary, Limnol. Oceanogr., 33, 1102-1115, 1988.

Cook, J., Edwards, A., Takeuchi, N., and Irvine-Fynn, T.: Cryoconite: the dark biological secret of the cryosphere, Prog. Phys. Geog., 40, 66-111, https://doi.org/10.1177/0309133315616574, 2016.

Darby, B. J. and Neher, D. A.: Stable isotope composition of microfauna supports the occurrence of biologically fixed nitrogen from cyanobacteria in desert soil food webs, J. Arid Environ., 85, 76-78, https://doi.org/10.1016/j.jaridenv.2012.06.006, 2012.

Degens, E. T., Guillard, R. R. L., Sackett, W. M., and Hellebust, J. A.: Metabolic fractionation of carbon isotopes in marine plankton - I. Temperature and respiration experiments, Deep Sea Research and Oceanographic Abstracts, 15, 1-9, https://doi.org/10.1016/0011-7471(68)90024-7, 1968.

DeNiro, M. J. and Epstein, S.: Influence of diet on the distribution of carbon isotopes in animals, Geochim. Cosmochim. Ac., 42, 495-506, https://doi.org/10.1016/0016-7037(78)90199-0, 1978.

DeNiro, M. J. and Epstein, S.: Influence of diet on the distribution of nitrogen isotopes in animals, Geochim. Cosmochim. Ac., 45, 341-351, doi.org/10.1016/0016-7037(81)90244-1, 1981.

Devetter, M.: Clearance rates of the bdelloid rotifer, Habrotrocha thienemanni, a tree-hole inhabitant, Aquat. Ecol., 43, 85-89, https://doi.org/10.1007/s10452-007-9160-9, 2009.
Donner, J.: Ordnung Bdelloidea (Rotatoria, Rädertiere), AkademieVerlag, Berlin, Germany, 297 pp., 1965.

Edwards, A., Douglas, B., Anesio, A. M., Rassner, S. M., Irvine-Fynn, T. D., Sattler, B., and Griffith, G. W.: A distinctive fungal community inhabiting cryoconite holes on glaciers in Svalbard, Fungal Ecol., 6, 168-176, https://doi.org/10.1016/j.funeco.2012.11.001, 2013a.

Edwards, A., Rassner, S. M., Anesio, A. M., Worgan, H. J., IrvineFynn, T. D., Wyn Williams, H., Sattler, B., and Wyn Griffith, G.: Contrasts between the cryoconite and ice-marginal bacterial communities of Svalbard glaciers, Polar Res., 32, 19468, https://doi.org/10.3402/polar.v32i0.19468, 2013 b.

Edwards, A., Mur, L. A., Girdwood, S. E., Anesio, A. M., Stibal, M., Rassner, S. M., Hell, K., Pachebat, J. A., Post, B., Bussell, J. S., Cameron, S. J. S., Wyn Griffith, G., Hodson, A. J., and Sattler, B.: Coupled cryoconite ecosystem structure-function relationships are revealed by comparing bacterial communities in alpine and Arctic glaciers, FEMS Microbiol. Ecol., 89, 222-237, https://doi.org/10.1111/1574-6941.12283, 2014.

Ekblad, A. and Högberg, P.: Analysis of $\delta^{13} \mathrm{C}$ of $\mathrm{CO}_{2}$ distinguishes between microbial respiration of added $\mathrm{C} 4$-sucrose and other soil respiration in a $\mathrm{C}_{3}$-ecosystem, Plant Soil, 219, 197-209, https://doi.org/10.1023/A:1004732430929, 2000.

Elser, J. J. and Urabe, J.: The stoichiometry of consumerdriven nutrient recycling: theory, observations, and consequences, Ecology, 80, 735-751, https://doi.org/10.1890/00129658(1999)080[0735:TSOCDN]2.0.CO;2, 1999.

Ettl, H. and Gärtner, G.: Syllabus der Boden-, Luft- und Flechtenalgen, Springer Spektrum, Berlin, Germany, 2014 (in German).

Foreman, C. M., Sattler, B., Mikucki, J. A., Porazinska, D. L., and Priscu, J. C.: Metabolic activity and diversity of cryoconites in the Taylor Valley, Antarctica, J. Geophys. Res.-Biogeo., 112, G04S32, https://doi.org/10.1029/2006JG000358, 2007.

Fountain, A. G., Tranter, M., Nylen, T. H., Lewis, K. J., and Mueller, D. R.: Evolution of cryoconite holes and their contribution to meltwater runoff from glaciers in the McMurdo Dry Valleys, Antarctica, J. Glaciol., 50, 35-45, https://doi.org/10.3189/172756504781830312, 2004.

Gerdel, R. W. and Drouet, F.: The cryoconite of the Thule area, Greenland, T. Am. Microsc. Soc., 79, 256-272, https://doi.org/10.2307/3223732, 1960.

Grzesiak, J., Górniak, D., Świątecki, A., Aleksandrzak-Piekarczyk, T., Szatraj, K., and Zdanowski, M. K.: Microbial community development on the surface of Hans and Werenskiold Glaciers (Svalbard, Arctic): a comparison, Extremophiles, 19, 885-897, https://doi.org/10.1007/s00792-015-0764-z, 2015.

$\mathrm{Gu}, \mathrm{B}$. and Alexander, V.: Estimation of $\mathrm{N}_{2}$ fixation based on differences in the natural abundance of ${ }^{15} \mathrm{~N}$ among freshwater $\mathrm{N}_{2}$-fixing and non- $\mathrm{N}_{2}$-fixing algae, Oecologia, 96, 43-48, https://doi.org/10.1007/BF00318029, 1993.

Guidetti, R., Altiero, T., and Rebecchi, L.: On dormancy strategies in tardigrades, J. Insect Physiol., 57, 567-576, https://doi.org/10.1016/j.jinsphys.2011.03.003, 2011.

Guidetti, R., Altiero, T., Marchioro, T., Amade, L. S., Avdonina, A. M., Bertolani, R., and Rebecchi, L.: Form and function of the feeding apparatus in Eutardigrada (Tardigrada), Zoomorphology, 131, 127-148, https://doi.org/10.1007/s00435-012-0149-0, 2012. 
Guil, N. and Sanchez-Moreno, S.: Fine-scale patterns in micrometazoans: tardigrade diversity, community composition and trophic dynamics in leaf litter, Syst. Biodivers., 11, 181-193, https://doi.org/10.1080/14772000.2013.798370, 2013.

Hagen, J., Liestøl, O., Roland, K., and Jørgensen, T.: Glacier Atlas of Svalbard and Jan Mayen, Norsk Polarinstitutt, Oslo, Norway, 141 pp., 1993.

Hallas, T. E. and Yeates, G. W.: Tardigrada of the soil and litter of a Danish beech forest, Pedobiologia, 12, 287-304, 1972.

Herzig, A., Gulati, R. D., Jersabek, C. D., and May, L.: Rotifera X: Rotifer Research: Trends, New Tools and Recent Advances, 181, Springer Science \& Business Media, Berlin, Germany, 2006.

Hinga, K. R., Arthur, M. A., Pilson, M. E., and Whitaker, D.: Carbon isotope fractionation by marine phytoplankton in culture: the effects of $\mathrm{CO}_{2}$ concentration, $\mathrm{pH}$, temperature, and species, Glob. Biogeochem. Cy., 8, 91-102, https://doi.org/10.1029/93GB03393, 1994.

Hodson, A. J., Mumford, P. N., Kohler, J., and Wynn, P. M.: The High Arctic glacial ecosystem: new insights from nutrient budgets, Biogeochemistry, 72, 233-256, https://doi.org/10.1007/s10533-004-0362-0, 2005.

Hodson, A., Anesio, A. M., Tranter, M., Fountain, A., Osborn, M., Priscu, J., Laybourn-Parry, J., and Sattler, B.: Glacial ecosystems, Ecol. Monogr., 78, 41-67, https://doi.org/10.1890/07-0187.1, 2008.

Hood, E., Fellman, J., Spencer, R. G., Hernes, P. J., Edwards, R., D'Amore, D., and Scott, D.: Glaciers as a source of ancient and labile organic matter to the marine environment, Nature, 462, 1044-1047, https://doi.org/10.1038/nature08580, 2009.

Iakovenko, N. S., Smykla, J., Convey, P., Kašparová, E., Kozeretska, I. A., Trokhymets, V., Dykyy, I., Plewka, M., Devetter, M., Duriš, Z., and Janko, K.: Antarctic bdelloid rotifers: diversity, endemism and evolution, Hydrobiologia, 761, 5-43, https://doi.org/10.1007/s10750-015-2463-2, 2015.

International Centre for Diffraction Data, JCPDS PDF-2 Database, ICDD, Newtown Square, Pennsylvania, USA, 2002.

Kaczmarek, Ł., Jakubowska, N., Celewicz-Gołdyn, S., and Zawierucha, K.: The microorganisms of cryoconite holes (algae, Archaea, bacteria, cyanobacteria, fungi, and Protista): a review, Polar Rec., 52, 176-203, https://doi.org/10.1017/S0032247415000637, 2016.

Kling, G. W., Fry, B., and O'Brien, W. J.: Stable isotopes and planktonic trophic structure in arctic lakes, Ecology, 73, 561-566, https://doi.org/10.2307/1940762, 1992.

Kohler, T. J., Stanish, L. F., Liptzin, D., Barrett, J. E., and McKnight, D. M.: Catch and release: Hyporheic retention and mineralization of $\mathrm{N}$-fixing Nostoc sustains downstream microbial mat biomass in two polar desert streams, Limnol. Oceanogr. Lett., 3 , 357-364, https://doi.org/10.1002/lol2.10087, 2018.

Kosztyła, P., Stec, D., Morek, W., Gąsiorek, P., Zawierucha, K., Michno, K., Ufir, K., Małek, D., Hlebowicz, K., Laska, A., Dudziak, M., Frohme, M., Prokop, Z. M., Kaczmarek, Ł., and Michalczyk, Ł.: Experimental taxonomy confirms the environmental stability of morphometric traits in a taxonomically challenging group of microinvertebrates, Zool. J. Linn. Soc., 178, 765-775, https://doi.org/10.1111/zoj.12409, 2016.

Kutikova, L. A.: Bdelloid rotifers (Rotifera, Bdelloidea) as a component of soil and land biocenoses, Biol. Bull. Russ. Acad. Sci., 30, 271-274, https://doi.org/10.1023/A:1023811929889, 2003.
Macko, S. A. and Estep, M. L.: Microbial alteration of stable nitrogen and carbon isotopic compositions of organic matter, Org. Geochem., 6, 787-790, https://doi.org/10.1016/01466380(84)90100-1, 1984.

Mariotti, A., Pierre, D., Vedy, J. C., Bruckert, S., and Guillemot, J.: The abundance of natural nitrogen 15 in the organic matter of soils along an altitudinal gradient (Chablais, Haute Savoie, France), Catena, 7, 293-300, https://doi.org/10.1016/S03418162(80)80020-8, 1980.

Marshall, W. A. and Chalmers, M. O.: Airborne dispersal of Antarctic terrestrial algae and cyanobacteria, Ecography, 20, 585-594, https://doi.org/10.1111/j.1600-0587.1997.tb00427.x, 1997.

McCutchan, J. H., Lewis, W. M., Kendall, C., and McGrath, C. C.: Variation in trophic shift for stable isotope ratios of carbon, nitrogen, and sulfur, Oikos, 102, 378-390, https://doi.org/10.1034/j.1600-0706.2003.12098.x, 2003.

Mialet, B., Majdi, N., Tackx, M., Azémar, F., and Buffan-Dubau, E.: Selective feeding of bdelloid rotifers in river biofilms, Plos One, 8, e75352, https://doi.org/10.1371/journal.pone.0075352, 2013.

Michener, R. and Lajtha, K.: Stable isotopes in ecology and environmental science, John Wiley \& Sons, New Jersey, USA, 2008.

Montoya, J. P., Horrigan, S. G., and McCarthy, J. J.: Natural abundance of ${ }^{15} \mathrm{~N}$ in particulate nitrogen and zooplankton in the Chesapeake Bay, Mar. Ecol.-Prog. Ser., 65, 35-61, 1990.

Mueller, D. R., Vincent, W. F., Pollard, W. H., and Fritsen, C. H.: Glacial cryoconite ecosystems: a bipolar comparison of algal communities and habitats, Nova Hedwigia Beiheft, 123, 173198, 2001.

Nagarkar, S., Williams, G. A., Subramanian, G., and Saha, S. K.: Cyanobacteria-dominated biofilms: a high quality food resource for intertidal grazers, Asian Pacific Phycology in the 21st Century: Prospects and Challenges, Springer, Dordrecht, Germany, https://doi.org/10.1007/978-94-007-0944-7_12, 89-95, 2004.

Nordenskiöld, A. E.: Cryoconite found 1870, July 19th-25th, on the inland ice, east of Auleitsivik Fjord, Disco Bay, Greenland, Geol. Mag., Decade, 2, 157-162, 1875.

Olive, P. J., Pinnegar, J. K., Polunin, N. V., Richards, G., and Welch, R.: Isotope trophic-step fractionation: a dynamic equilibrium model, J. Anim. Ecol., 72, 608-617, https://doi.org/10.1046/j.1365-2656.2003.00730.x, 2003.

O’Reilly, C. M., Verburg, P., Hecky, R. E., Plisnier, P. D., and Cohen, A. S.: Food web dynamics in stable isotope ecology: time integration of different trophic levels, Handbook of Scaling Methods in Aquatic Ecology, CRC Press, USA, 145-154, 2003.

Peterson, B. J. and Fry, B.: Stable isotopes in ecosystem studies, Annu. Rev. Ecol. Syst., 18, 293-320, 1987.

Ponsard, S. and Arditi, R.: What can stable isotopes $\left(\delta^{15} \mathrm{~N}\right.$ and $\delta^{13} \mathrm{C}$ ) tell about the food web of soil macro-invertebrates?, Ecology, 81, 852-864, https://doi.org/10.1890/00129658(2000)081[0852:WCSINA]2.0.CO;2, 2000.

Porazinska, D. L., Fountain, A. G., Nylen, T. H., Tranter, M., Virginia, R. A., and Wall, D. H.: The biodiversity and biogeochemistry of cryoconite holes from McMurdo Dry Valley glaciers, Antarctica, Arct. Antarct. Alp. Res., 36, 84-91, https://doi.org/10.1657/15230430(2004)036[0084:TBABOC]2.0.CO;2, 2004.

Post, D. M.: Using stable isotopes to estimate trophic position: models, methods, and assumptions, Ecol- 
ogy, $\quad 83, \quad 703-718, \quad$ https://doi.org/10.1890/00129658(2002)083[0703:USITET]2.0.CO;2, 2002.

Ramazzotti, G. and Maucci, W.: II Phylum Tardigradum, Terza edizione riveduta e corretta, Memorie dell'Istituto Italiano di Idrobiologia Dott, Marco Marchi, Pallanza, Italy, 41, 1-1012, 1983 (in Italian).

R Development Core Team: R: a language and environment for statistical computing, Vienna, Austria, available at: https://www. R-project.org (last access: 23 February 2021), 2018.

Ricci, C.: Dormancy patterns in rotifers, Hydrobiologia, 446, 1-11, https://doi.org/10.1023/A:1017548418201, 2001.

Roberts, J. A., Hughes, B. T., and Fowle, D. A.: Micro-scale mineralogic controls on microbial attachment to silicate surfaces: iron and phosphate mineral inclusions, in: Water-Rock Interaction, in: Proceedings of the Eleventh International Symposium on WaterRock Interaction WRI-11, Saratoga Springs, NY, USA, 27 June2 July 2004, 1149-1153, 2004.

Šantrůček, J., Šantrůčková, H., Kaštovská, E., Květoň, J., Tahovská, K., Vrábl, D., and Vráblová, M.: Stabilní isotopy biogeních prvků: použití v biologii a ekologii, Academia, Czech Republic, 2018 (in Czech).

Säwström, C., Mumford, P., Marshall, W., Hodson, A., and Laybourn-Parry, J.: The microbial communities and primary productivity of cryoconite holes in an Arctic glacier (Svalbard 79 N), Polar Biol., 25, 591-596, https://doi.org/10.1007/s00300-0020388-5, 2002.

Shaw, E. A., Adams, B. J., Barrett, J. E., Lyons, W. B., Virginia, R. A., and Wall, D. H.: Stable $\mathrm{C}$ and $\mathrm{N}$ isotope ratios reveal soil food web structure and identify the nematode Eudorylaimus antarcticus as an omnivore-predator in Taylor Valley, Antarctica, Polar Biol., 41, 1013-1018, https://doi.org/10.1007/s00300-017-22438, 2018.

Starmach, K.: Cyanophyta-sinice (Cyanophyta-blue-green algae), Flora słodkowodna Polski, 2, PAN - Państw. Wyd. Nauk., Warszawa, Poland, 807 pp., 1966.

Stibal, M., Tranter, M., Benning, L. G., and Řehák, J.: Microbial primary production on an Arctic glacier is insignificant in comparison with allochthonous organic carbon input, Environ. Microbiol., 10, 2172-2178, https://doi.org/10.1111/j.14622920.2008.01620.x, 2008.

Stibal, M., Lawson, E. C., Lis, G. P., Mak, K. M., Wadham, J. L., and Anesio, A. M.: Organic matter content and quality in supraglacial debris across the ablation zone of the Greenland ice sheet, Ann. Glaciol., 51, 1-8, https://doi.org/10.3189/172756411795931958, 2010.

Stibal, M., Šabacká, M., and Žárský, J.: Biological processes on glacier and ice sheet surfaces, Nat. Geosci., 5, 771, https://doi.org/10.1038/ngeo1611, 2012a.

Stibal, M., Telling, J., Cook, J., Mak, K. M., Hodson, A., and Anesio, A. M.: Environmental controls on microbial abundance and activity on the Greenland ice sheet: a multivariate analysis approach, Microbial Ecol., 63, 74-84, https://doi.org/10.1007/s00248-011-9935-3, 2012b.

Střítecká, M. and Devetter, M.: Sledování filtrační aktivity vî́níků v kryokonitech, Senior high school thesis, Česko-anglické gymnasium, 27 pp., České Budějovice, Czech Republic, 2015 (in Czech).

Takeuchi, N., Kohshima, S., and Seko, K.: Structure, formation, and darkening process of albedo-reducing material (cry- oconite) on a Himalayan glacier: a granular algal mat growing on the glacier, Arct. Antarct. Alp. Res., 33, 115-122, https://doi.org/10.1080/15230430.2001.12003413, 2001.

Telling, J., Anesio, A. M., Tranter, M., Irvine-Fynn, T., Hodson, A., Butler, C., and Wadham, J.: Nitrogen fixation on Arctic glaciers, Svalbard, J. Geophys. Res.-Biogeo., 116, G03039, https://doi.org/10.1029/2010JG001632, 2011.

Telling, J., Anesio, A. M., Tranter, M., Stibal, M., Hawkings, J., Irvine-Fynn, T., Hodson, A., Butler, C., Yallop, M., and Wadham, J.: Controls on the autochthonous production and respiration of organic matter in cryoconite holes on high Arctic glaciers, J. Geophys. Res.-Biogeo., 117, G01017, https://doi.org/10.1029/2011JG001828, 2012.

Velázquez, D., Jungblut, A. D., Rochera, C., Rico, E., Camacho, A., and Quesada, A.: Trophic interactions in microbial mats on Byers Peninsula, maritime Antarctica, Polar Biol., 40, 1115-1126, https://doi.org/10.1007/s00300-016-2039-2, 2017.

Vindušková, O., Jandová, K., and Frouz, J.: Improved method for removing siderite by in situ acidification before elemental and isotope analysis of soil organic carbon, J. Plant Nutr. Soil Sc., 182, 82-91, https://doi.org/10.1002/jpln.201800164, 2019.

Vonnahme, T. R., Devetter, M., Žárský, J. D., Šabacká, M., and Elster, J.: Controls on microalgal community structures in cryoconite holes upon high-Arctic glaciers, Svalbard, Biogeosciences, 13, 659-674, https://doi.org/10.5194/bg-13-659-2016, 2016.

Wada, E.: Stable $\delta^{15} \mathrm{~N}$ and $\delta^{13} \mathrm{C}$ isotope ratios in aquatic ecosystems, P. Jpn. Acad. B, 85, 98-107, https://doi.org/10.2183/pjab.85.98, 2009.

Wagenbach, D., Preunkert, S., Schäfer, J., Jung, W., and Tomadin, L.: Northward transport of Saharan dust recorded in a deep Alpine ice core, The impact of desert dust across the Mediterranean, Springer, Dordrecht, Germany, 291-300, https://doi.org/10.1007/978-94-017-3354-0_29, 1996.

Wallace, R. L. and Snell, T. W.: Rotifera, Ecology and classification of North American Freshwater Invertebrates, Academic Press, USA, 173-235, 2010.

Wehr, J. D., Sheath, R. G., and Kociolek, J. P.: Freshwater algae of North America: ecology and classification, Elsevier, USA, 2015.

Williams Jr., R. S. and Ferrigno, J. G.: State of the Earth's cryosphere at the beginning of the 21st century: Glaciers, global snow cover, floating ice, and permafrost and periglacial environments, Director, 508, 344-6840, 2012.

Xu, Y., Simpson, A. J., Eyles, N., and Simpson, M. J.: Sources and molecular composition of cryoconite organic matter from the Athabasca Glacier, Canadian Rocky Mountains, Org. Geochem., 41, 177-186, https://doi.org/10.1016/j.orggeochem.2009.10.010, 2010.

Yoshii, K., Melnik, N. G., Timoshkin, O. A., Bondarenko, N. A., Anoshko, P. N., Yoshioka, T., and Wada, E.: Stable isotope analyses of the pelagic food web in Lake Baikal, Limnol. Oceanogr., 44, 502-511, https://doi.org/10.4319/lo.1999.44.3.0502, 1999.

Zah, R., Burgherr, P., Bernasconi, S. M., and Uehlinger, U.: Stable isotope analysis of macroinvertebrates and their food sources in a glacier stream, Freshwater Biol., 46, 871-882, https://doi.org/10.1046/j.1365-2427.2001.00720.x, 2001.

Žárský, J. D., Stibal, M., Hodson, A., Sattler, B., Schostag, M., Hansen, L. H., Jacobsen, C. S., and Psenner, R.: Large cryoconite aggregates on a Svalbard glacier support a diverse microbial 
community including ammonia-oxidizing archaea, Environ. Res. Lett., 8, 035044, https://doi.org/10.1088/1748-9326/8/3/035044, 2013.

Zawierucha, K., Kolicka, M., Takeuchi, N., and Kaczmarek, Ł.: What animals can live in cryoconite holes? A faunal review, J. Zool., 295, 159-169, https://doi.org/10.1111/jzo.12195, 2015.

Zawierucha, K., Ostrowska, M., Vonnahme, T. R., Devetter, M., Nawrot, A. P., Lehmann, S., and Kolicka, M.: Diversity and distribution of Tardigrada in Arctic cryoconite holes, J. Limnol., 75, 545-559, https://doi.org/10.4081/jlimnol.2016.1453, 2016.

Zawierucha, K., Buda, J., Pietryka, M., Richter, D., Łokas, E., Lehmann-Konera, S., Makowska, N., and Bogdziewicz, M.: Snapshot of micro-animals and associated biotic and abiotic environmental variables on the edge of the south-west Greenland ice sheet, Limnology, 19, 141-150, https://doi.org/10.1007/s10201-017-0528-9, 2018a.

Zawierucha, K., Stec, D., Lachowska-Cierlik, D., Takeuchi, N., Li, Z., and Michalczyk, Ł.: High mitochondrial diversity in a new water bear species (Tardigrada: Eutardigrada) from mountain glaciers in central Asia, with the erection of a new genus Cryoconicus, Annal. Zool., 68, 179-202, https://doi.org/10.3161/00034541ANZ2018.68.1.007, 2018b.

Zawierucha, K., Buda, J., and Nawrot, A.: Extreme weather event results in the removal of invertebrates from cryoconite holes on an Arctic valley glacier (Longyearbreen, Svalbard), Ecol. Res., 34, 370-379, https://doi.org/10.1111/1440-1703.1276, 2019a.

Zawierucha, K., Buda, J., Fontaneto, D., Ambrosini, R., Franzetti, A., Wierzgoń, M., and Bogdziewicz, M.: Fine-scale spatial heterogeneity of invertebrates within cryoconite holes, Aquat. Ecol., 53, 179-190, https://doi.org/10.1007/s10452-019-09681$9,2019 b$.
Zawierucha, K., Baccolo, G., Di Mauro, B., Nawrot, A., Szczuciński, W., and Kalińska, E.: Micromorphological features of mineral matter from cryoconite holes on Arctic (Svalbard) and alpine (the Alps, the Caucasus) glaciers, Polar Sci., 22, 100482, https://doi.org/10.1016/j.polar.2019.100482, 2019c.

Zawierucha, K., Buda, J., Novotna Jaromerska, T., Janko, K., and Gąsiorek, P.: Integrative approach reveals new species of water bears (Pilatobius, Grevenius, and Acutuncus) from Arctic cryoconite holes, with the discovery of hidden lineages of Hypsibius, Zool. Anz., 289, 141-165, https://doi.org/10.1016/j.jcz.2020.09.004, 2020.

Zawierucha, K., Porazinska, D. L., Ficetola, G. F., Ambrosini, R., Baccolo, G., Buda, J., Ceballos, J. L., Devetter, M., Dial, R., Franzetti, A., Fuglewicz, U., Gielly, L., Łokas, E., Janko, K., Novotna Jaromerska, T., Kościński, A., Kozłowska, A., Ono, M., Parnikoza, I., Pittino, F., Poniecka, E., Sommers, P., Schmidt, S. K., Shain, D., Sikorska, S., Uetake, J., and Takeuchi, N.: A hole in the nematosphere: tardigrades and rotifers dominate the cryoconite hole environment, whereas nematodes are missing, J. Zool., 313, 18-36, https://doi.org/10.1111/jzo.12832, 2021. 